\title{
22. REPORT ON THE PETROGRAPHY OF A PALEOCENE BROWN COAL SAMPLE FROM THE NINETYEAST RIDGE, INDIAN OCEAN
}

\author{
A. C. Cook, Wollongong University College, Wollongong, N.S.W., Australia
}

The samples recovered from Site 214, Core 46, CC consisted of a piece of wood, preserved as xylite, together with some material which appeared earthy in hand specimen. The earthy material consisted mainly of small fragments of xylite together with some highly degraded plant material. All of the material appears to be a vitrinite precursor.

The oil reflectivity $(\lambda=525 \mathrm{~nm} \mu$ oil $=1.516)$ is constant over the samples (within the reproducibility error of the apparatus) at $0.20 \%$. This value is extremely low and is similar to values found for some components of peats and brown coals. On the basis of data from offshore bores this value is reasonably consistent with normal heat flow for a depth of 425 meters since there has been little progression along the rank series. No cellulose was observed (cellulose is present in the brown coals at Yallourn and Morwell).

Much of the xylite shows crushed cell structure (Plate 1), but most of the material has a vitrinite precursor in the cell lumens so that it resembles the telinite of bituminous coals. Some cell lumens are open (Plate 2), but many of the structures are quite compact. The cell walls tend to stand out in strong relief from the lumens due to the differences in polishing hardness, but the reflectivity of the walls and lumens is essentially the same.
Small specks of pyrite and some poorly formed framboidal pyrite are present (Plate 1). Some partly oxidized spherulitic masses of siderite were also noted (Plate 3). Siderite does coexist in coals with minor amounts of pyrite, but is generally confined to coals which show little or no evidence of marine influence in the immediately overlying strata.

The texture of the earthy material is typical of that for a brown coal (e.g., Plate 4). There are no features to suggest anything other than an autochthonous origin for the coal. Cell structures in the woody tissue are often very well preserved (Plate 5), but textures associated with fungal attack are also present (Plate 6).

It is difficult to use the data of Karweil (1956) for such low rank material, but an upper limit of $30^{\circ} \mathrm{C}$ effective coalification temperature can be given, and $20^{\circ} \mathrm{C}$ is the most probably figure..

\section{REFERENCE}

Karweil, J. 1956. Die Metamorphose der Kohlen vom Standpunkt der physikalischen Chemie: $\mathbf{Z}$. deutsch geol. Ges., v. 107, p. 132. 
PLATE 1

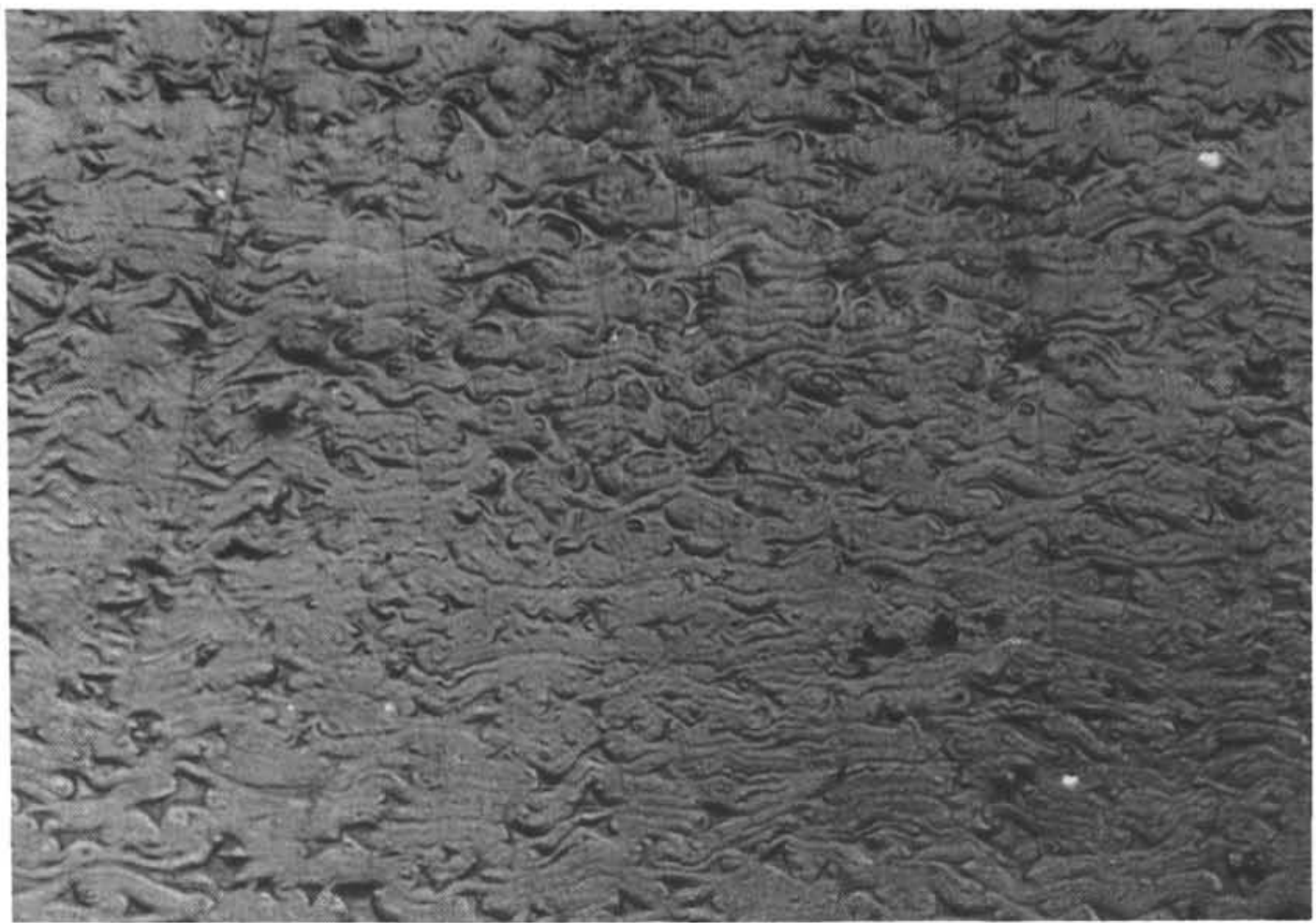

Typical cell structure in the xylite with the cell walls standing out in positive relief. The bright specks are poorly developed framboidal pyrite. (Plane polarized light, oil immersion, $\times 356$ ).

\section{PLATE 2}

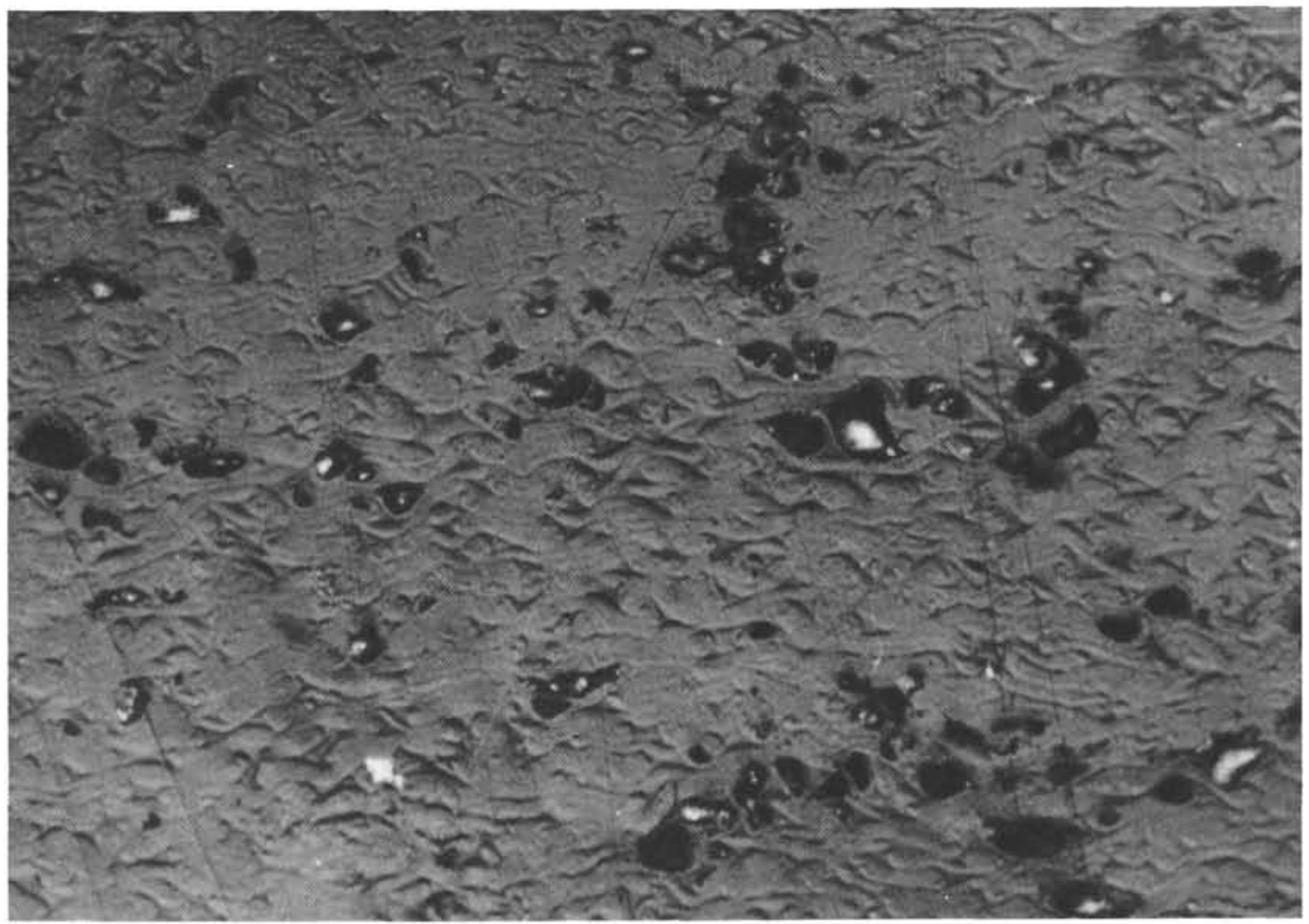

Cell structure with some open cell lumens. (Plane polarized light, oil immersion, $\mathrm{X} 356$ ). 


\section{PLATE 3}

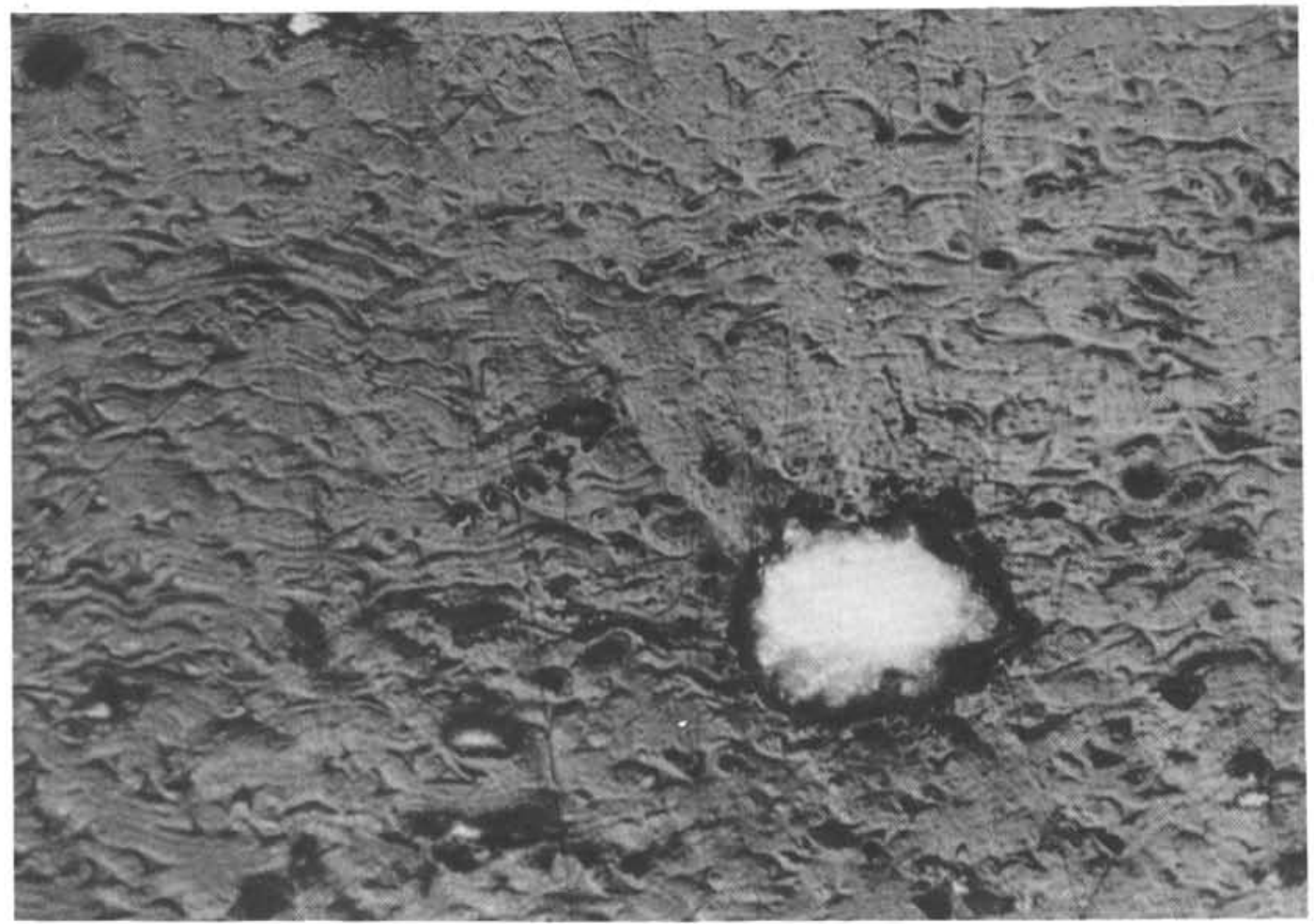

Partially oxidized siderite nodule in xylite. (Plate polarized light, oil immersion, $\mathrm{X} 356$ ).

\section{PLATE 4}

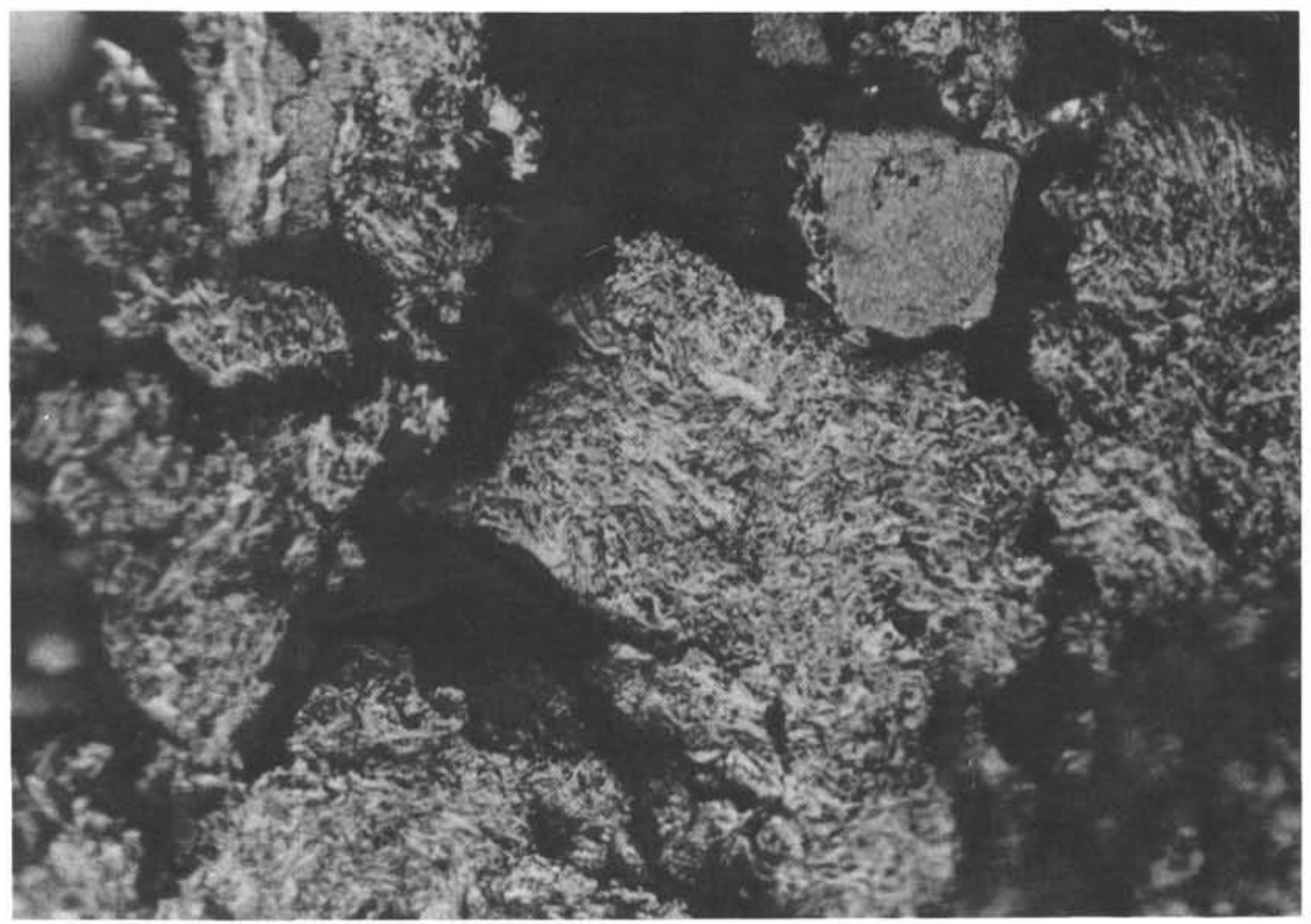

Degraded plant material. The texture is typical of the degradinite of Tertiary coals. (Plane polarized light, oil immersion, X356). 


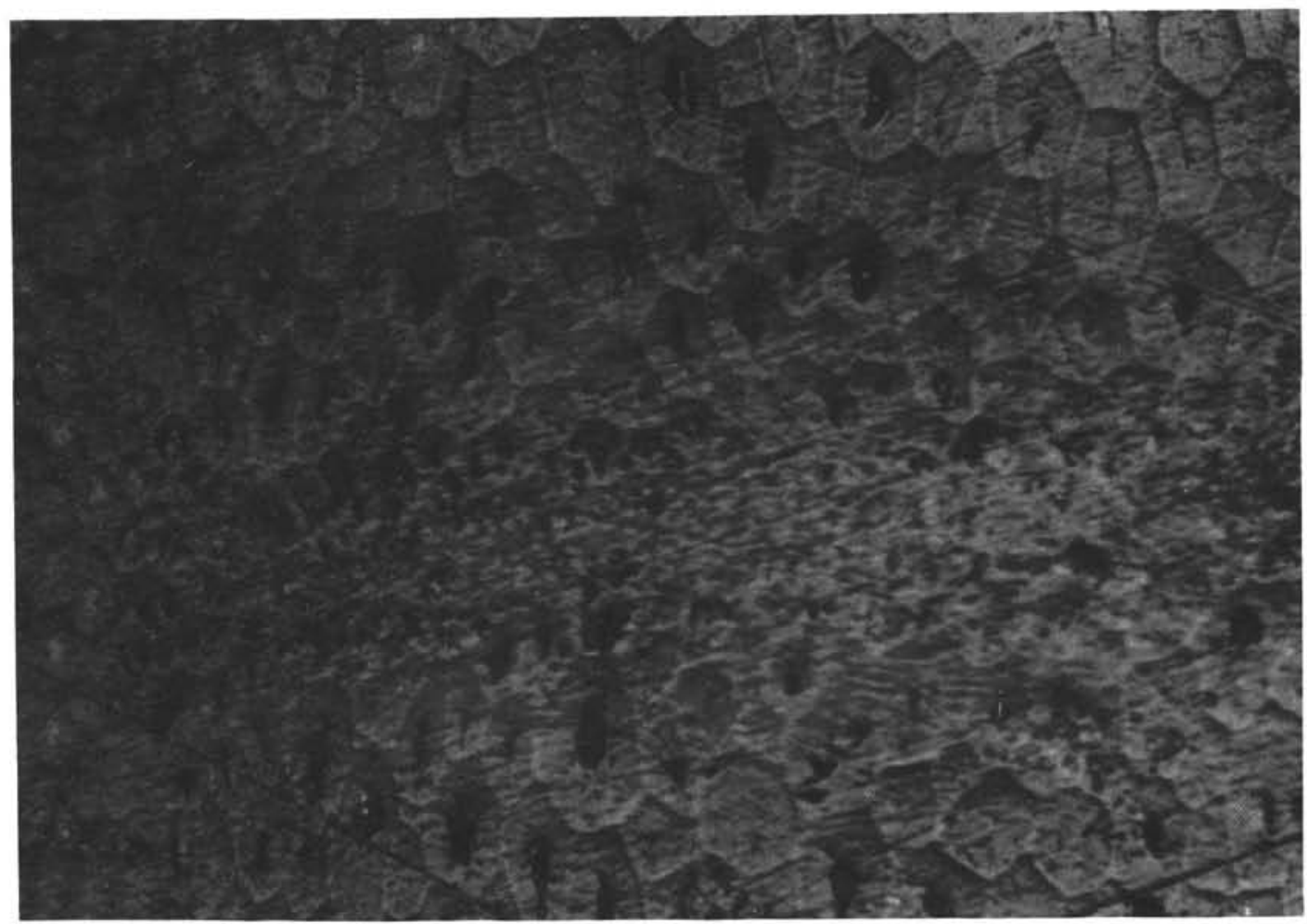

Well-preserved cell structures showing primary and secondary cell walls. (Plane polarized light, oil immersion, X356).

\section{PLATE 6}

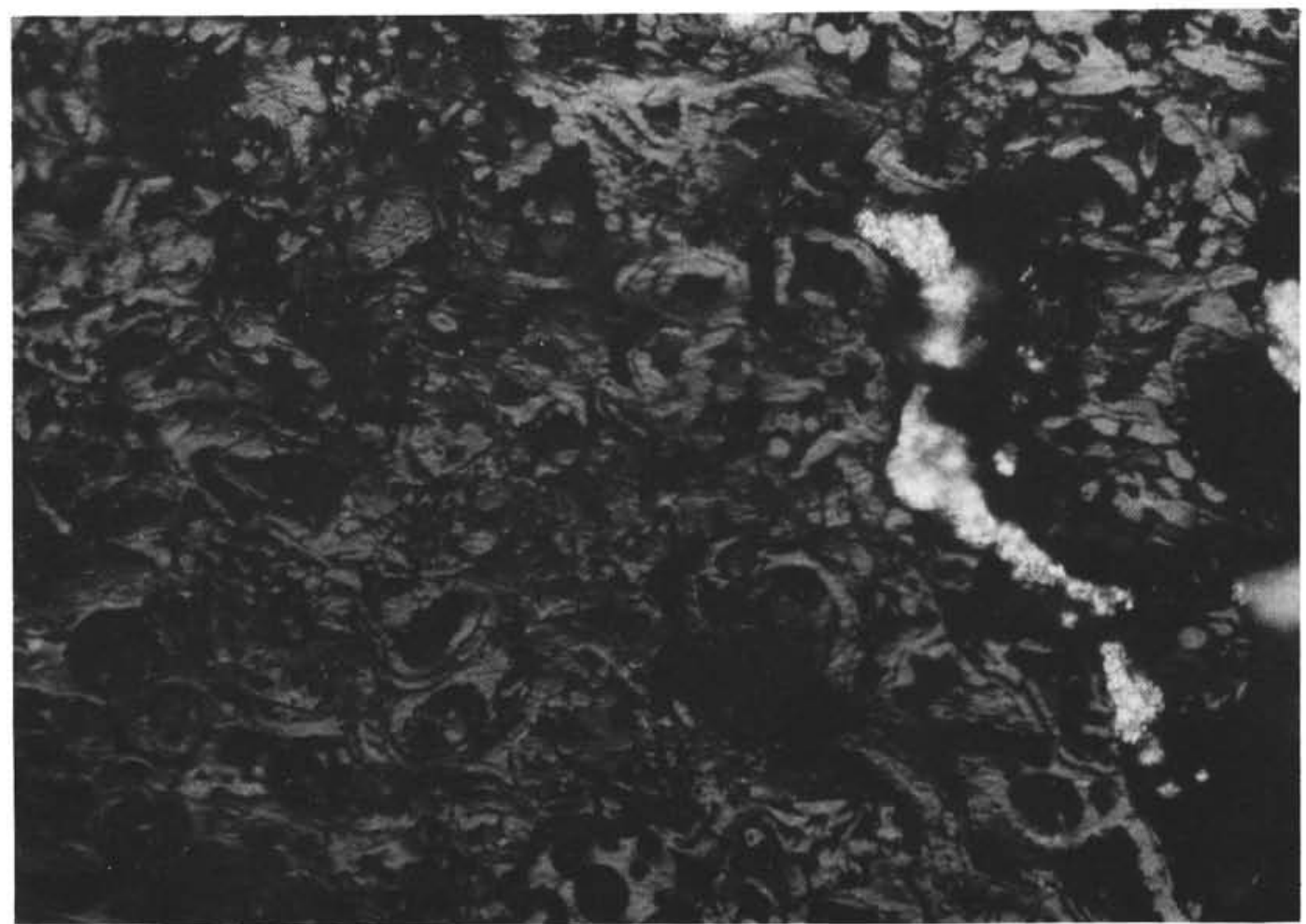

Partially degraded plant cells. The form of the degradation is one which is often associated with fungal activity, but no undoubted fungal hyphae can be distinguished. (Plane polarized light, oil immersion, $\times 356)$. 